\title{
PENERAPAN ALGORITMA DAN PEMROGRAMAN BERBASIS WEB PADA UJI JONCKHEERE-TERPSTRA
}

\author{
ALEX MARDIANA, NARWEN, YUDIANTRI ASDI \\ Program Studi S1 Matematika, \\ Fakultas Matematika dan Ilmu Pengetahuan Alam, Universitas Andalas, \\ Kampus UNAND Limau Manis Padang, Indonesia. \\ email : alexmardiana17@gmail.com
}

Diterima 29 November Direvisi 3 Desember 2019 Dipublikasikan 12 Januari 2020

\begin{abstract}
Abstrak. UNAND ON DATA adalah program kerja yang paling diutamakan dari Kementerian Riset dan Pengembangan Badan Eksekutif Mahasiswa Keluarga Mahasiswa Universitas Andalas. Untuk membantu pelaksanaan program kerja tersebut akan dibuat aplikasi uji-uji statistik. Sebagai langkah awal untuk membuat aplikasi tersebut maka penulis akan membuat prototype-nya dengan membuat algoritma dan bahasa program berbasis WEB untuk uji statistik nonparametrik Jonckheere-Terpstra.
\end{abstract}

Kata Kunci: Pemrograman WEB, Jonckheere, Terpstra

\section{Pendahuluan}

Kementerian Riset \& Pengembangan adalah salah satu kementerian yang ada di Badan Eksekutif Mahasiswa Keluarga Mahasiswa Universitas Andalas. Program kerja yang paling diutamakan dari kementerian tersebut adalah UNAND ON DATA, yaitu sebuah website open data yang berisi informasi terkait dengan Universitas Andalas. Untuk mempercepat proses dalam melaksanakan program kerja tersebut dibutuhkan aplikasi pengolah data yang instan, simpel, dan praktis. Oleh karena itu penulis berinisiatif untuk membuat aplikasi uji-uji statistik berbasis WEB. Penulis memulai dengan membuat prototype dari aplikasi uji-uji statistik tersebut karena untuk membuat aplikasi tersebut secara lengkap membutuhkan waktu yang lama dan biaya yang besar. Sebagai prototype penulis memilih salah satu uji nonparametrik yaitu Uji Jonckheere-Terptra (uji JT) untuk contoh kecil dengan $\alpha=0.05$ dan pengujian satu sisi. Berdasarkan uraian tersebut maka ingin diketahui apa algoritma dari uji JT, bagaimana bahasa program berbasis web dari uji JT, dan bagaimana penggunaan program berbasis web dari uji JT untuk membuat algoritma dan bahasa program berbasis WEB sebagai prototype dari aplikasi uji-uji statistik. 


\section{Landasan Teori}

Bahasa program berbasis WEB yang penulis gunakan terdiri dari tiga komponen utama yaitu, HTML, PHP, dan XAMPP. Dalam [2] HTML (HyperText Markup Language) adalah bahasa pemformatan teks untuk dokumen-dokumen pada jaringan komputer yang sering disebut sebagai World Wide Web. Dalam [1] PHP (Hypertext Preprocessor) adalah bahasa server-side-scripting yang menyatu dengan HTML untuk membuat halaman WEB yang dinamis. Dalam [4] XAMPP (X(windows/linux) Apache MySQL PHP dan Perl) merupakan paket server WEB PHP dan database MySQL yang paling populer di kalangan pengembang WEB dengan menggunakan PHP dan MySQL sebagai database-nya.

Dalam [3] telah dijelaskan bahwa statistik uji Jonckheere-Terpstra digunakan untuk menguji hipotesis nol bahwa tidak ada perbedaan median antar $k$ contoh melawan hipotesis alternatif antar $k$ contoh memiliki median yang berurutan. Hipotesis dapat ditulis dengan:

$$
\begin{aligned}
& H_{0}: \theta_{1}=\theta_{2}=\cdots=\theta_{k} \\
& H_{1}: \theta_{1} \leq \theta_{2} \leq \cdots \leq \theta_{k} ; \text { setidaknya } \theta_{j}<\theta_{j^{\prime}}, j^{\prime}=j+1
\end{aligned}
$$

Dalam [3] juga dijelaskan langkah-langkah dalam uji Jonckheere-Terpstra yaitu, pertama menentukan banyaknya statistik Mann-Whitney, kedua menghitung statistik Mann-Whitney untuk setiap pasangan contoh terurut dengan rumus

$$
U_{u v}=\sum_{j=1}^{n_{u}} \sum_{j^{\prime}=1}^{n_{v}} \phi\left(x_{j u}, x_{j^{\prime} v}\right)
$$

dimana

$$
\phi\left(x_{j u}, x_{j^{\prime} v}\right)=\left\{\begin{array}{l}
1, \text { jika } x_{j u}<x_{j^{\prime} v} \\
\frac{1}{2}, \text { jika } x_{j u}=x_{j^{\prime} v} \\
0, \text { jika } x_{j u}>x_{j^{\prime} v}
\end{array}\right.
$$

ketiga menghitung statistik uji Jonckheere-Terpstra sebagai penjumlahan dari statistik Mann-Whtney dengan rumus

$$
J=\sum_{u=1}^{v-1} \sum_{v=2}^{k} U_{u v}
$$

keempat pengambilan keputusan, Jika nilai $J \geq J_{\alpha}$, maka tolak $H_{0}$.

\section{Pembahasan}

Dalam penelitian ini telah dilakukan studi literatur mengenai WEB dan komponen Pembangun WEB serta studi literatur mengenai langkah-langkah yang harus dilakukan untuk melakukan uji Jonckheere-Terpstra. Dari studi literatur tersebut diperoleh algoritma sebagai berikut.

Algoritma uji Jonckheere-Terpstra untuk pemrograman berbasis WEB

(1) Input banyak baris sebagai jumlah_baris (baris terbanyak dari seluruh kolom yang akan diuji) dan input banyak kolom sebagai jumlah_kolom dengan fungsi POST. 
Penerapan Algoritma dan Pemrograman Berbasis WEB pada Uji Jonckheere-Terpstra 11

(2) Input $i s i_{i j} ; i=0,1, \cdots$,jumlah_baris -1 dan $j=0,1, \cdots$, jumlah_kolom -1 dengan fungsi POST.

(3) Input $h_{0}$ dan $h_{1}$ (berupa kesimpulan dan kesimpulan alternatif yang ingin diuji) dengan fungsi POST.

(4) Membuat koneksi ke database. Jika database ada maka lanjutkan ke langkah berikutnya, jika tidak maka buat database secara manual manggunakan MySQL.

(5) Periksa apakah tabel dalam database ada. Jika ada maka lanjutkan ke langkah berikutnya, jika tidak ada maka buat tabel terlebih dahulu.

(6) Menyimpan jumlah_baris, jumlah_kolom, $i s i_{i j}, h_{0}$, dan $h_{1}$ ke dalam database

(7) Memanggil kembali jumlah_baris, jumlah_kolom, $i s i_{i j}, h_{0}$, dan $h_{1}$ yang telah disimpan di database sebelumnya.

(8) Menampilkan $i s i_{i j}$ ke dalam tabel di WEB.

(9) Menghitung statistik Mann-Whitney dan menghitung statistik uji JonckheereTerpstra sebagai hasil penjumlahan dari statistik Mann-Whitney atau mencari $J_{\text {hitung. }}$.

(10) Menghitung $n_{j} ; j=0,1, \cdots$,jumlah_kolom - 1

(11) Membandingkan $J_{\text {hitung }}$ dengan $J_{\text {tabel }}$ dan menampilkan hasil uji JonckheereTerpstra

\section{Kesimpulan}

Berdasarkan hasil dan pembahasan yang diperoleh maka dapat diambil kesimpulan yaitu: Pertama, uji Jonckheere-Terpstra dapat diubah menjadi sebuah algoritma sederhana yang dapat diterjemahkan ke dalam bahasa program berbasis WEB. Kedua, dengan merubah uji Jonckheere-Terpstra menjadi uji statistik berbasis WEB maka penggunaannya jauh lebih mudah dan lebih cepat dibandingkan dengan melakukan uji tersebut secara manual. Ketiga, uji Jonckheere-Terpstra cocok dijadikan prototype uji statistik berbasis WEB karena langkah-langkah pengerjaan uji ini cukup kompleks sehingga akan mempermudah pengembangan untuk uji-uji statistik lainnya pada masa yang akan datang.

\section{Ucapan Terima kasih}

Puji syukur kehadirat Allah SWT yang telah memberikan kesehatan dan kelancaran dalam membuat tulisan ini. Terimakasih penulis ucapkan kepada Bapak Dr. Effendi, Ibu Dr. Susila Bahri dan Bapak Zulakmal, M.Si atas kritik dan saran yang telah disampaikan sebagai penguji. Terimakasih penulis ucapkan kepada Ibu Nova Noliza Bakar, M.Si selaku pembimbing akademik yang telah membimbing penulis dari awal hingga akhir perkuliahan. Penulis juga mengucapkan terimakasih kepada kedua orang tua, sahabat-sahabat dan teman-teman yang telah memberikan dukungan kepada penulis dalam menyelesaikan tulisan ini.

\section{Daftar Pustaka}

[1] Arief, M. R., 2011, Pemrograman Web Dinamis Menggunakan PHP dan $M y S Q L$, ANDI, Yogyakarta 
12 Alex Mardiana

[2] Nugroho, A., 2006, E-Commerce, Informatika, Bandung

[3] Sakina, F. I., Maria, B. M., 2015, Penerapan Uji Jonckheere-Terpstra untuk Menguji Hipotesis Alternatif Berurut pada k Conth Bebas (Studi Kasus Sikap Ibu Primigravida terhadap Perubahan Fisiologi Kehamilan Trimester I), Universitas Brawijaya, Malang

[4] Sidik, B., 2012, Pemrograman Web dengan PHP, Informatika, Bandung 